\title{
Origami as a Tool to Teach Geometry for Blind Students
}

\author{
Tania Maria Moratelli Pinho' ${ }^{1}$ Cristina Maria Carvalho Delou ${ }^{2,3}$, Neuza Rejane Wille Lima ${ }^{3}$ \\ ${ }^{1}$ Instituto Benjamin Constant, Rio de Janeiro, RJ, Brazil \\ ${ }^{2}$ Pós-Graduação em Ciências e Biotecnologia, Instituto de Biologia, Univerdade Federal Fluminense, Niterói, RJ, Brazil \\ ${ }^{3}$ Curso de Mestrado Ptofissional em Diversidade e Inclusão, Instituto de Biologia, Univerdiade Federal Fluminense, Niterói, RJ, Brazil \\ Email: rejane_lima@id.uff.br
}

How to cite this paper: Pinho, T. M. M., Delou, C. M. C., \& Lima, N. R. W. (2016). Origami as a Tool to Teach Geometry for Blind Students. Creative Education, 7, 26522665.

http://dx.doi.org/10.4236/ce.2016.717249

Received: October 18, 2016

Accepted: November 13, 2016

Published: November 16, 2016

Copyright $\odot 2016$ by authors and Scientific Research Publishing Inc. This work is licensed under the Creative Commons Attribution International License (CC BY 4.0).

http://creativecommons.org/licenses/by/4.0/

\begin{abstract}
The teaching of mathematics involves logical and abstract reasoning that is often associated with belief, prejudices and difficulties. Therefore, students can develop an aversion to this science. This scenario may be even more complex when it involves blind students. However, creative didactic and pedagogical practices can help to deconstruct such adversities. The aim of the study was to test if eight workshops that were carried out the making four origami pieces (a small Box at it covers, a Rabbit face, and a "Bandeirinha de São João"-small flag of St. John party) could promote the construction of knowledge about geometry in 14 blind students. These students from the sixth to ninth year of elementary school are regularly enrolled of Benjamin Constant Institute, RJ, Brazil, and intend the after class. Eight workshops with $100 \mathrm{mi}$ nutes each were conducted in September and October $2015(\mathrm{n}=4)$ and in March and April $2016(n=4)$. Among eight paper types offered for students to make origami the kinds, we identified that the papers denominated waxed and sulfite were those who favored the realization of folds while Kraft one facilitated favored the discovery of the folds. On average, the questions concerning the geometric shapes and their elements obtained by the origami were answered correctly by eight students both for making the Box and its cover; as for the Rabbit face, and by ten students for making of small flag of St. John party. These results demonstrated the effectiveness of origami to teaching math to teenagers blind students.
\end{abstract}

\section{Keywords}

Brazilian Folk Festivals, Educational Strategies, Fun Activities, Inclusive Education, Mathematics, Visually Impaired, Teenagers

\section{Introduction}

The students look for the mathematics that generally involves beliefs about prejudices 
and difficulties, leading to aversion to this science. The relationship of students with mathematics depends on their skills, their social contexts, and the moment of school life and the teachers' ability to introduce this discipline as well (Onder, 2009).

We can add to this complexed reality the cases of students with special needs, whose physical and/or mental conditions may provide a greater or lesser ability in understanding the educational content (Pinho, 2016; Pinho \& Lima, 2016a, 2016b; Pinho et al., 2016).

Thus, in order to obtain a better school performance, it will be up to the teacher to adopt inclusive curriculum and to encourage and support the students and their family during the process of educational and social inclusion (Cunha, 2011; Giannini \& Delou, 2016; Lima \& Delou, 2016; Pinho, 2016; Pinho \& Lima, 2016a, 2016b; Pinho et al., 2016).

The inclusive curriculum involves modifications of planning, objectives, activities and assessment methods to ensure the involvement of students with special needs inside a school class (Paraná, 2006).

In this context, the adequacy of certain mathematics theoretical concepts for students with visual impairment should take into account that exists among them an exaggerated aversion to this subject, especially with regard to topics that depend on vision for better understanding necessary about geometric shapes and its elements (D'Ambrosio, 1986; Pinho \& Lima, 2016a, 2016b).

But this reality can be modified because

"Teaching is to looking for to discover interests, gestures, needs and student problems, choosing content, techniques and strategies, providing appropriate materials and create favorable environment for study." (Karling, 1991: p. 23).

"In the teacher's deposition, it was possible to see that when the teacher said he likes his subject, he suggested to be important to pass this 'taste' to the students. This concern is revealed in the describe that value actions like: encouraging students' participation, stimulating the students' questions, stimulating to create the daily studying habit, encouraging the student to produce the Math knowledge." (Berticelli et al., 2016: p. 2513).

In this sense, it was created the challenge of using the playfulness that involves folding paper (origami) to complement lessons on geometric figures and their elements for blind students of elementary school during the after class turn.

The relationship between origami and mathematics lessons is not an innovation and it is inducible the numerous possibility for the use of this rich tool in the pedagogical point of view (Cavalcanti \& Furuya, 2009; Rezende \& Queiroz, 2000; Suzuki et al., 2006).

Rêgo et al. (2003) pointed out that

"The origami can represent to the teaching/learning of Mathematics an important methodological resource, through which the students will expand their formal geometric knowledge initially acquired informally through observation of the 
world of objects and shapes that surround. With a manual activity that includes, among other fields of knowledge, Geometry and Art ...” (Rêgo et al., 2003: p. 18).

\section{Objective}

The objective of this study was to test if eight workshops that were carried out the making four origami pieces (a small Box at it cover, a Rabbit face, and a "Bandeirinha de São João"-a small flag of St. John party) could promote the construction of knowledge about geometry in 14 blind students. These students from the sixth to ninth year of elementary school are regularly enrolled of Benjamin Constant Institute, RJ, Brazil. These origami pieces were folded during the after class turn, involving to identify among eight types of papers the most appropriate to promote and evaluate the construction of knowledge about geometric shapes and its elements through recreational activities.

\section{Methodology}

Before starting the study, three legal steps were fulfilled. First, the project entitled "New perspectives of teaching practices in the journey of the student with visual impairment" which involved the workshops of the present study was submitted to the ethics committee of Platforma Brasil and to the Benjamin Constant Institute as well. The Brazil platform is a national and unified basis of research involving human subject records for the entire system (Plataforma Brasil, 2016).

Additionally, before the activities begin consent term was sent to all parents and guardians of the 14 students who were involved in this study. The consent forms were confectioned both ink as well as in Braille.

The workshops $(n=8)$ to fabricate four pieces of origami (Figures 1-3) were carried out during the after classes to complete the regular geometry classes for the second segment of elementary school from the sixth to ninth year of elementary school.

These workshops were held lasting 100 minutes with 14 blind students enrolled Benjamin Constant Institute during the months of September and October 2015 ( $n=4)$

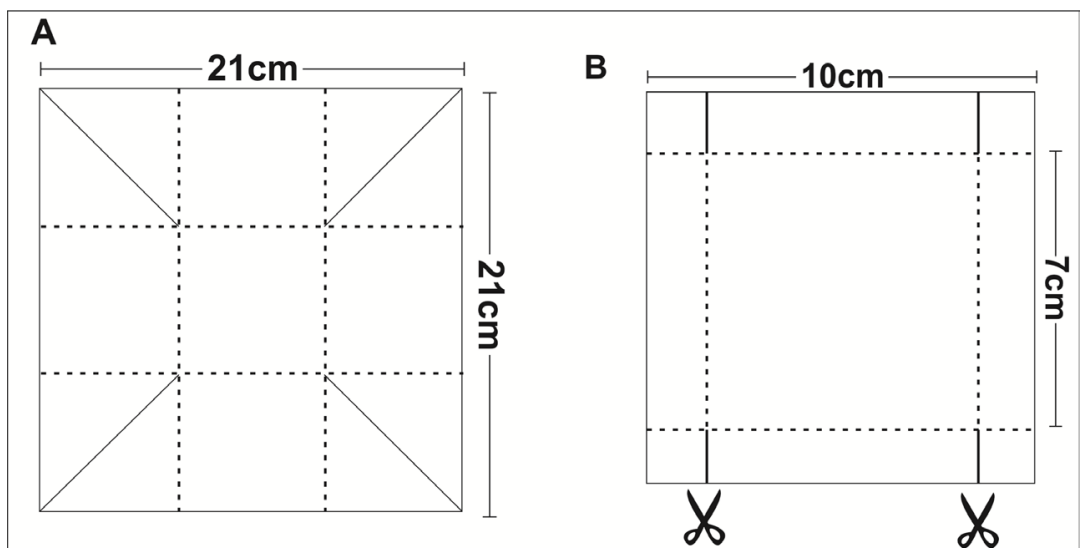

Figure 1. Diagram to guide the making of Box (A) and its cover (B) used to address the square concepts and fractions. 


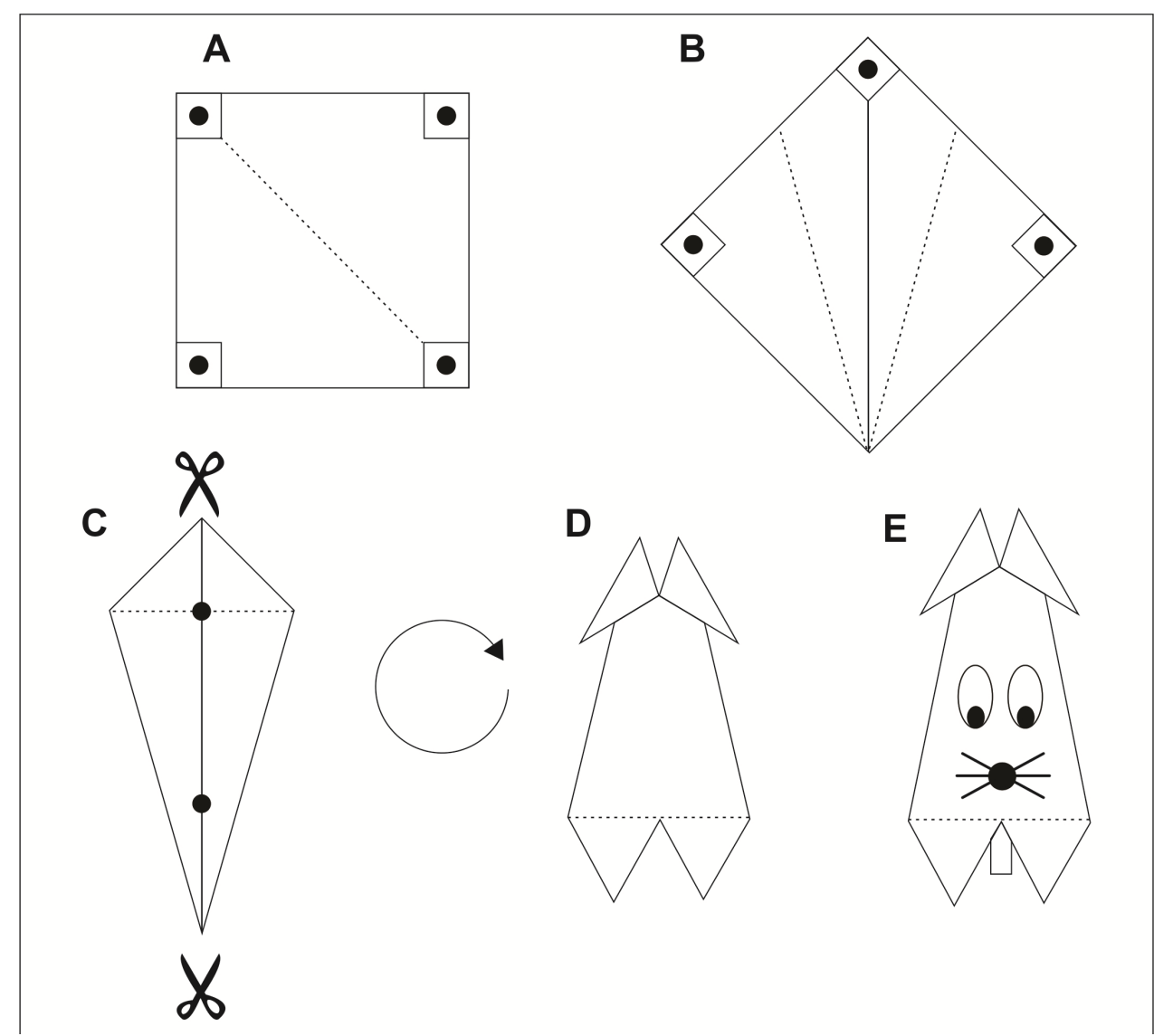

Figure 2. Origami diagram of Rabbit Face: (A) Square, (B) Square indicating the folds, (C) Lozenge (ice cream cone) with medians indication (points), (D) Pentagon with two above triangles (ears) and two triangles below (tie), (E) Rabbit face with toothpaste in the shape of rectangle.

and March and April $2016(\mathrm{n}=4)$.

The manufacture of the first two parts: Box with cover, was produced in order to address one of the students everyday objects (Figure 1).

The production of two pieces: the Rabbit face (Figure 2) and a small flag of St. John party (Figure 3), took up the theme the celebration of Passover and the Brazilian June festivals, respectively.

The pedagogical planning workshops involved four steps. First, to carry out the necessary procedures for using origami as an educational resource. Second, to seek the most appropriate way for the development the workshops either through diagram or through descriptions. Third, to choose the type of paper more suitable for use in origami construction, considering both weight of paper and it accessibility. Fourth, to address and evaluate the geometry content and its elements each of 14 students received an envelope containing eight sheets of paper, cut into the shape of a square, pertaining to eight types of paper with different weights, but with the same size (Table 1).

The first contact with eight papers allowed the student to discover what would be the most appropriate paper for making the folds and identify the folds of origami.

Additionally, it was delivered to each student a plastic pallet that is used by dentists 


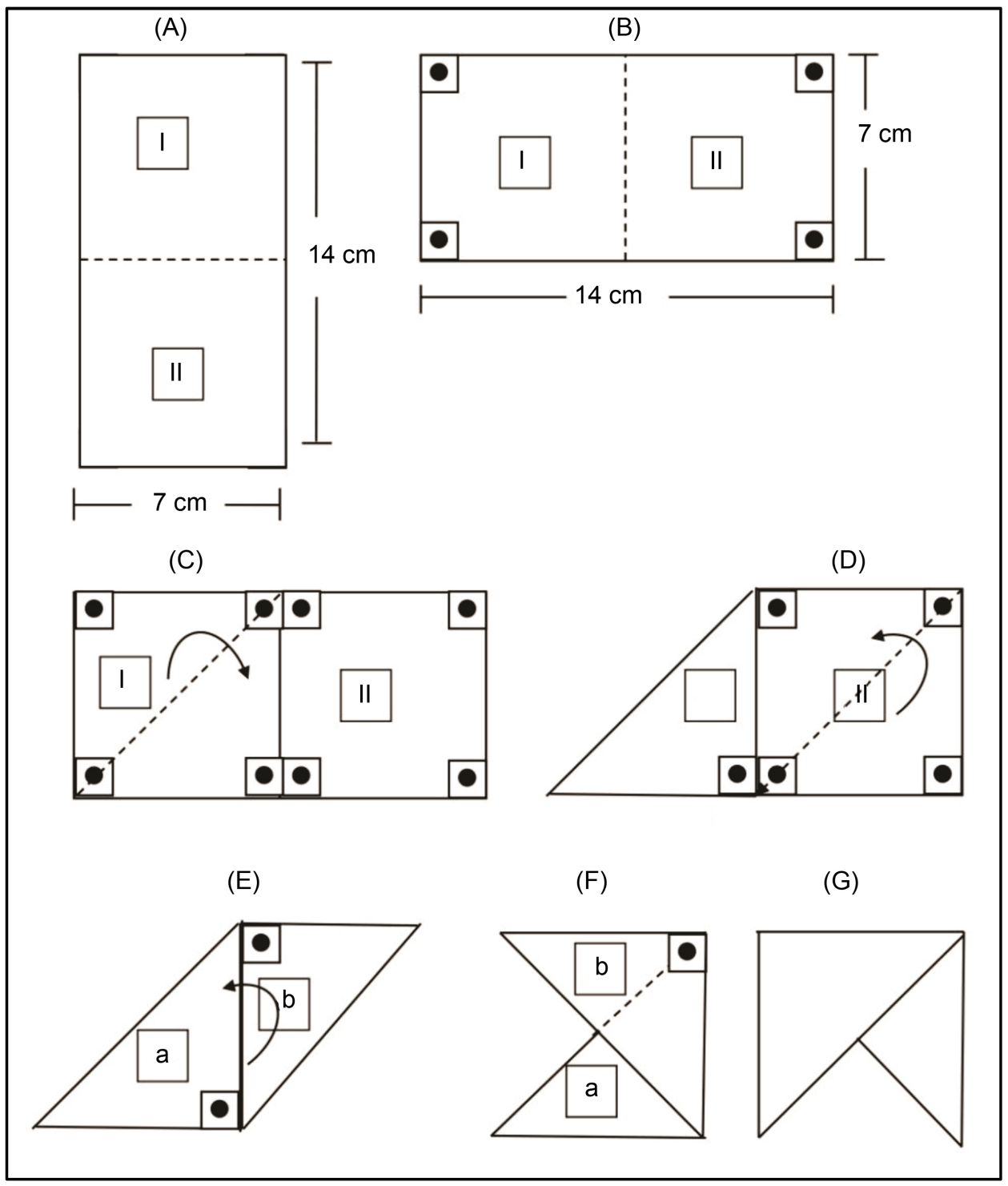

Figure 3. Origami diagram of small flag of St. John party showing one rectangle two squares (part I and II; (A)-(C));. (D) Trapeze; (E) Parallelogram; (F) Figure Concove; (G) The small flag of St. John party.

and a scissors adapted to blind persons.

The plastic pallet allowed each student to crease the folds in the paper. The scissors was used to make small cuts in the origami on the Box cover (Figure 1) and the ears of Rabbit face (Figure 2).

We asked each student to handle all eight types of papers they received (Table 1) and the indicated folder, during the execution of four pieces of origami (Figures 1-3) and point out those who favored the foreclosure of folding.

The focus of the observation was to detect the level of prior knowledge of the participants had in relationship to the weight of the paper and the way in dealing with them and recognize the shape and its geometric elements. 
Table 1. Types of papers provided for the students choose discover what would be the most appropriate paper for making and identify the folds of origami.

\begin{tabular}{ccc}
\hline Types of paper & Weigh $\left(\mathrm{g} / \mathrm{m}^{2}\right)$ & Dimensions $\left(\mathrm{cm}^{2}\right)$ \\
\hline 1. Tissue & 13 & 225 \\
2. Laminated & 30 & 225 \\
3. Waxed & 50 & 225 \\
4. Parchment & 60 & 225 \\
5. Sulfite & 75 & 225 \\
6. Color plus & 80 & 225 \\
7. Couché & 90 & 225 \\
8. Kraft & 110 & 225 \\
\hline
\end{tabular}

The folding of Box allowed addressing the geometric shapes on the square and its fractions (Figure 1). With Rabbit face were approached the concepts about square, triangle, rhombus and medians, parallelogram, pentagon, and rectangle (Figure 2). From the preparation of small flag of St. John party (Figure 3), it was built the concepts of trapeze, the parallelogram and the concave figure.

At the end, we applied individually a series of questions (Tables 2-4) to verify whether the construction of knowledge of students through the activities developed was reached.

\section{Results}

The project to carry out the present study received from the Plataforma Brasil the number CAAE-44054715.4.0000.5243, on June 16, 2015. It was approved by the expert report belonging the Plataforma Brasil (2016) through the number 1,220,127, on September 9, 2015. The Benjamin Constant Institute also approved this project, by fulfillment of the requirements for conducting research in this federal agency. More over all consent forms were signed by the heads of the 14 students involved in the research and were later filed at the Benjamin Constant Institute.

The selected students involved in the study represented a homogeneous group. They were blind, between 14 to 17 years old (mean age 16 years old), involving seven females and seven males. Two of the students belonged to the 6th year, six the 7 th year, four to 8 years and two to 9th years of elementary school, covering all the years of this stages of basic education in Brazil.

As we expected, during the first workshop it was verified that the students had great difficulty handling the offered papers. They took the papers and kneaded such that they were unsuitable for assembly to construct the origami pieces proposed. Through this practice, it was observed that about $80 \%$ of the students had never had contact with another paper that was not the one that is used to write Braille or those to print newspapers and magazines.

The students began to demonstrate more skill with the papers after teaching intervention. She helped each student on the handling and identification of eight types of 
Table 2. Questions to assess the content covered with the making of the Box and its cover (Figure 1).

\begin{tabular}{|c|c|}
\hline $\mathrm{N}^{\circ}$ & Questions \\
\hline 01 & What is the fraction representing the whole of the planned figure? \\
\hline 02 & If we take the two squares of the top and the two the bottom, where the resulting fraction? \\
\hline 03 & $\begin{array}{l}\text { What fraction of the square of the housing cover is in relation to the nine that used to build the } \\
\text { box? }\end{array}$ \\
\hline 04 & $\begin{array}{l}\text { When the diagonals of the square ends were folded triangles formed. What is the name of the } \\
\text { sides of these triangles? }\end{array}$ \\
\hline 05 & What fraction of the planned part of the box that you put together is? \\
\hline 06 & $\begin{array}{l}\text { Each palpable face of the box, is what fraction of total tangible faces of the assembled box? } \\
\text { NOTE: opening the box will not be counted as face. }\end{array}$ \\
\hline
\end{tabular}

Table 3. Questions to assess the content covered in the preparation of rabbit face (Figure 2).

\begin{tabular}{ll}
$N^{\circ}$ & \multicolumn{1}{c}{ Questions } \\
01 & Have you ever consumed an ice cream using a cone made with cookies? \\
02 & Can you identify any similarities between the figures doubled, early on, with the ice cream \\
03 & Does the way you turned the "Cone" give to get ice cream? \\
04 & What would be the non-planar geometric figure that could be used to put the ice cream? \\
05 & What is the flat geometric figure that gave rise to face the rabbit? \\
06 & When we called a vertex to another non-consecutive, we're talking about? \\
07 & That plane geometric figures formed after double the half of the diagonal bisect angles? \\
08 & How many degrees each angle was when bisect was bent? \\
09 & What line segment name that was used to be cut and that resulted in the tie rabbit? \\
10 & The tie of the Rabbit face was represented by two triangles. How would you rate such as \\
11 & Whiangles on the sides and angles?
\end{tabular}

each paper offered, explaining how the differences in weight and specificity of them.

Each student initiated the montage activities of origami by holding the tips of papers and joined those that were indicated by the teacher, so to follow the bends (Figures 1-3) as well as to make cuts in the case of the Box cover and the ear of the Rabbit face (Figure 1 and Figure 2).

When it was asked the students only to discover what were the existing folds in distributed plane figures to build the Box and it cover (Figure 1) it was observed that about $70 \%$ of them said it difficult to find these geometric elements. The other $30 \%$ had no trouble finding the folds and completed the montage without any difficulty.

To fabricate the Box and its cover (Figure 1) the parchment paper was the one that most students chose. The making of the Rabbit face (Figure 2) was easier when using 
Table 4. Questions to assess the content covered in the flag making Saint John party (Figure 3).

\begin{tabular}{ll}
\hline $\mathrm{N}^{\circ}$ & \multicolumn{1}{c}{ Questions } \\
\hline 01 & What is the measure of height relative to the length? \\
02 & What is the fraction that represents the ratio of the measurement of length and height \\
& measurement? \\
03 & What geometric figure came when we put the right triangle with the square? \\
05 & The union between the triangle and the square, there was a trapeze. The lower base of the \\
06 & As for the angles, what kind of trapeze was formed? \\
07 & What kind of polygon formed through construction of the small lag of St. John party? \\
08 & $\begin{array}{l}\text { The side that is unparalleled in the trapeze was the right triangle. What is the name of this } \\
\text { side of the triangle? }\end{array}$ \\
09 & How many right angles were formed in figure built? \\
10 & In the steps of the construction of the flag, it formed a quadrangle. What is his name?
\end{tabular}

the papers of types waxed and sulfite therefore, are those that most facilitated achievement of the folds. In order to do the small flag of St. John party (Figure 3) the sulfite paper was the most appropriate. However, the Kraft paper was the one who facilitated much the discovery of the folds because of this high weight.

The individual oral survey on the preference by students which papers would be easier to work with all origami pieces was applied during the second workshop. It was observed that about $60 \%$ of students rejected the tissue paper to be very flexible. About $40 \%$ of students rejected the laminated paper; but they did not know how clearly defined the main cause. However it was realized that no acceptance can be associated with poor adherence. Around $90 \%$ of students voted in the parchment papers, sulfite and Kraft, in this order, as the preferred papers to build the origami pieces. They claimed it would be "easy roles hold them". Finally, approximately $10 \%$ of students opted for the waxed paper.

Altogether they were applied twenty-eight questions about geometric shapes and their elements by building box and its lid $(n=6)$, the face of the Rabbit $(n=12)$ of small flag of St. John party $(n=10)$ (Tables 2-4).

In the third and fourth workshops, six questions apply from the making of the Box and its cover (Table 2) three of them were answered correctly by $100 \%$ of students ( $\mathrm{n}=$ 14) (Table 5). However, only two students correctly answered the three other issues related to the contents related to fractions

In the fifth and sixth workshops, twelve questions applied from the making of the Rabbit face, five of them were answered correctly by $100 \%$ of students. Additionally, two questions were answered correctly by about $60 \%$, and three by about $30 \%$. Finally, only one student (Table 3 and Table 6) answered a question related to the pentagon correctly.

In the seventh and eighth workshops, ten questions applied from the confection of 
Table 5. Number of students (n) from 14 who correctly answered questions related to the making of the Box and its cover (Table 2).

\begin{tabular}{ccc}
\hline Questions & Expected answers & (n) \\
\hline 1 & $9 / 9$ & 14 \\
2 & $5 / 9$ & 14 \\
3 & $1 / 9$ & 02 \\
4 & Peccaries and hypotenuse & 02 \\
5 & $18 / 9$ & 14 \\
6 & $1 / 5$ & 02
\end{tabular}

Table 6. Number of students (n), from 14, who correctly answered questions related to the preparation of Rabbit face (Table 3 ).

\begin{tabular}{ccc}
\hline Questions & Expected answers & (n) \\
\hline 01 & Yes & 14 \\
02 & Yes & 14 \\
03 & Rectangle & 08 \\
04 & 06 & 14 \\
05 & Some points were raised in relative to the table plane & 14 \\
06 & Edge & 04 \\
07 & 12 & 05 \\
08 & Vertex & 08 \\
09 & 08 & 04 \\
10 & Pentagon & 14 \\
11 & Rectangle & 01 \\
12 & & 14 \\
\hline
\end{tabular}

the small Flag of St. John party (Table 4 and Table 7) four of them were answered correctly by $100 \%$ of students, two for about $85 \%$ of the students, two for about $50 \%$ of students.

Only issues related to scalene figures and concave, were correctly identified by only two students (less than $15 \%$ of the total) (Table 4 and Table 7).

On average, the questions related to geometric shapes and its elements of the small flag of St. John and of Rabbit face were correctly answered by eight students (Table 5 and Table 6). On average, ten students (Table 7) responded the correct answers on the geometric and its elements involved in the confection of small flag of St. John party. All together, these results showed that the workshops with origami help most of the student to understand and build knowledge on the issues geometric figures.

\section{Discussion}

The successful use of origami in workshops that address geometric figures knowledge 
Table 7. Number of students (n), from 14, who correctly answered questions related to the preparation of small flag of St. John party (Table 4).

\begin{tabular}{ccc}
\hline Questions & Expected answers & $(\mathrm{n})$ \\
\hline 1 & The double & 14 \\
2 & $1 / 2$ & 11 \\
3 & Trapeze & 08 \\
4 & Square & 13 \\
5 & Scalene & 02 \\
6 & Rectangle & 14 \\
7 & Concave & 02 \\
8 & Hypotenuse & 07 \\
9 & Two & 14 \\
10 & Parallelogram & 14 \\
\hline
\end{tabular}

with blind students suggests that is strategy can be adopted both in special schools for the visually impaired people as inclusive schools that also involves students who see. The origami involves two fields of knowledge: geometry and art that represent which features numerous educational applicability and it is inducible the numerous possibility for the use of this rich tool in the pedagogical point of view (Rêgo et al., 2003; Cavalcanti \& Furuya, 2009; Suzuki et al., 2006; Rezende \& Queiroz, 2000).

We did not found any studies involving the use of origami in math classes for elementary school regarding the construction of knowledge of basic geometry content and fractions, for carrying out such activities involving blind students. A single study involving two blind students of high school class that was conducted by Pontes (2010) was found. This author evaluated the influence of the use of modular origami in the teaching and learning of spatial geometry, in particular to verify the relationship of Euler. She found that both the two blind students like 43 seers from a public school took the same educational advantage from the origami as a tool for learning mathematics.

This scenario suggests that probably there is a playful potential of origami in mathematics education for the visually impaired students. Perhaps this is a promising research field that lacks investment because it could be verified that the strategy of using origami in teaching mathematics was effective both in the study by Pontes (2010) which involved seers and blind that belonged to same class of the 2nd year of high school as well as in the present study (Pinho, 2016; Pinho \& Lima, 2016a, 2016b).

As said the Japanese origami maker Tomoko Fuse in 1990: "Every origami begins when we put the hands in motion. Therefore, there is a big difference between knowing something through the mind and know the same thing by touch." Considering touch as main ally the construction of knowledge of the visually impaired, the study of geometry see origami as an important instrument to be use in the process of learning these subjects, since students have direct contact with the material, can bend, unfold, cut and even fit the pieces to assemble figures. Therefore, this strategy may always have com- 
ponents that can be worked in mathematics lessons (Cavalcanti \& Furuya, 2009; Suzuki et al., 2006; Rêgo et al., 2003). We observed that students who conducted the workshops of origami proposed in this study experienced such experiences.

As stated Rezende \& Queiroz,

"Origami is a powerful tool for the teaching of mathematics. It is one of the rare opportunities in the teaching of mathematics where you can put the 'hand' in the object of study." (Rezende \& Queiroz, 2000: p. 13).

This process can encourage the construction of knowledge about elements of geometry for the blind or sighted students. In this context, one can also consider the quote from Karling which states:

"... teaching is to seek out interests, tastes, needs and student problems; choose content, techniques and strategies; provide adequate materials and create favorable environment for study." (Karling, 1991: p. 23).

This statement underlines the need to consolidate the search materials for math teaching involving visually impaired students. For these students, materials and recreational resources play an important role in the construction of knowledge.

According to Baumel \& Castro (2003),

“... establish a professional development process, characterizing their practice as innovative and creative, based on the use and analysis of materials and resources, considering the teaching of media. In this issue, encouraging continuing education and the pursuit of personal and professional development of teachers are undoubtedly crucial conditions for experiments and analysis of the degree of innovation resulting materials." (Baumel \& Castro, 2003: p. 106).

Today the field of mathematics encompasses many skills, including geometry, arithmetic, algebra, statistics, which are limited viewing or impossible by visually impaired students, especially the blind. These situations occur because math does not operate only by numbers and calculations, but also to relationships, classes, sets and groups, and also by geometric figures involving several geometric concepts such as, plane, angles and shapes that are difficult to understand by the visually impaired.

To account for this variety of these mathematical concepts, the systems of representation have become complex, reaching levels of abstraction that challenge teachers.

According to Reily (2004),

“... without special resources for blind students they will have enough trouble to keep up the matter in the early grades of elementary school, as well as from the 5th year when the requirements begin to increase." (Reily, 2004: p. 60).

The teaching of mathematical content involving visual concepts such as geometry should be adapted through description, tactile and auditory information that promotes understanding of the elements. The schemes, symbols and diagrams present were described orally or represented by objects. Drawings, graphics and illustrations should be 
adapted and represented in relief. The use of the origamis by Pontes (2010) proved the effective of this in building the concept of regular polyhedral by blind students and seers as well.

According to Pontes (2010), "solid manipulation constructed with modular origami techniques, through the haptic system, replaces perception characteristics that would be possible only through display". In the same way, the present it was elaborated a didactic sequence that promoted to the cognitive development of blind students from their potential.

The case of the experiencing with geometry through origami made with nice papers to the touch was consolidated with this experience means that were leading to facilitate the process of teaching and learning of mathematics of the visually impaired. This result confirms the considerations of Sá et al. (2007). They showed that when educational materials are based on criteria and according to the age and reliable range as its originality, especially when the contents that have the instrument vision as preponderance, the results will be well successful. It has been observed by the present study and others tha when teaching involves fun activities such as the use of origimi and educational games the construction of knowledge by students with visual impairment becomes more significant (Pinho \& Lima, 2016b).

\section{Conclusion}

In conclusion, we can learn and take advantage of the recreational and educational practice to fabricate origami was a widely reached purpose in geometry workshops given to 14 blind students of the second segment of the elementary school of the Benjamin Constant Institute. It could be observed that the origami was a very nice feature and pleasant and efficient to address the geometrical concepts and their elements to teenagers and blind students.

\section{Acknowledgements}

C. M. Delou thanks the CNPq (National Counsel of Technological and Scientific Development) for his research fellowship. The study received support from Benjamin Constant Institute and Fluminense Federal University.

\section{References}

Baumel, R. C. R. C., \& Castro, A. M. (2003). Materiais e Recursos de Ensino para Deficientes Visuais (Materials and Teaching Resources for the Visually Impaired). In M. L. S. Ribeiro, \& R. C. R. C. Baumel (Eds.), Educação especial: do querer ao fazer (pp. 95-107). São Paulo, SP: Avercamp.

Berticelli, D. D., Pinto, N. B., \& Migliavacca, P. (2016). Successful Practices in Mathematics in the End of Elementary School. Creative Education, 7, 2504-2514. http://dx.doi.org/10.4236/ce.2016.716237

Cavalcanti, E., \& Furuya, Y. K. S. (2009). Explorando Geometria com Origami (Exploring Geometry with Origami). Universidade Federal de São Carlos, 2009.

http://www.dm.ufscar.br/ yolanda/origami/origami.pdf 
Cunha, E. (2011). Práticas pedagógicas para a inclusão e a diversidade (Pedagogical Practices for Inclusion and Diversity). Rio de Janeiro: WAK Editora.

D’Ambrosio, U. (1986). Da realidade à ação: reflexões sobre Educação e Matemática (From Reality to Action: Reflections on Education and Mathematics). São Paulo: SUMMUS, Unicamp.

Fuse, T. (1990). Unit Origami: Multidimensional Transformations (Origami: Multidimensional Transformations). Japan Publication Inc.

Giannini, L. R., \& Delou, C. M. C. (2016). Visão da família sobre a diversidade e a inclusão (Family Outlook on Diversity and Inclusion). In N. R. W. Lima, \& C. M. C. Delou (Eds.), Ponto de vista em diversidade e inclusão (Cap. 18, pp. 136-139). Niterói, RJ: ABDInAssociação Brasileira de Diversidade e Inclusão.

Karling, A. A. A. (1991). Didática Necessária (The Required Didactic). São Paulo, SP: IBRASA.

Lima, N. R. W., \& Delou, C. M. C. (2016). Pontos de vista em diversidade e inclusão (Views on Diversity and Inclusion). Niterói, RJ: ABDIn-Associação Brasileira de Diversidade e Inclusão.

Onder, A. D. O. (2009). Olhar do aluno para a matemática (The Look of the Student for Mathematics). IX Congresso Nacional de Educação. Curitiba, PR: PUCPR.

Paraná (2006) Secretaria de Estado de Educação. Superintendência de Educação. Diretrizes Curriculares da Educação Especial para a Construção de Currículos Inclusivos (Special Education Curriculum Guidelines for Building Inclusive Curriculum). Curitiba, PR: SEED/ SUED. http://portal.mec.gov.br/seesp/arquivos/pdf/diretrizes.pdf

Pinho, T. M. M. (2016). A adaptação de materiais pedagógicos para o ensino de matemática para estudantes com deficiência visual do ensino fundamental ( $\sigma^{\circ}$ ao $9^{\circ}$ ano) (Adaptation of Teaching Materials for the Teaching of Mathematics for Students with Visual Impairment Elementary School (6th to $9^{t} h$ Years). Masters Dissertation (Mestrado em Diversidade e Inclusão), Niterói, RJ, Universidade Federal Fluminense.

Pinho, T. M. M., \& Lima, N. R. W. (2016a). O desafio de ensinar matemática às escuras (The Challenge of Teaching Mathematics in the Dark). In N. R. W. Lima, \& C. M. C. Delou (Eds.), Ponto de vista em diversidade e inclusão (Cap. 10, pp. 69-84). Niterói, RJ: ABDIn- Associação Brasileira de Diversidade e Inclusão.

Pinho, T. M. M., \& Lima, N. R. W. (2016b). Dobrando sacolas de plástico: Um instrumento no ensino de geometria para estudantes cegos do ensino fundamental (Folding Plastic Bags: A Tool in the Teaching of Geometry for Blind Students of Elementary School). Natal, RN: III Congresso Brasileiro de Educação-III CONEDU.

Pinho, T. M. M., Castro, H. C., Alves, L., \& Lima, N. R. W. (2016). Mathematics and Blindness: Let's Try to Solve This Problem? Scholedge International Journal of Multidisciplinary \& Allied Studies, in publication.

Plataforma Brasil (2016).

http://www.saude.sp.gov.br/centro-de-referencia-e-treinamento-dstaids-sp/pesquisa/comite-d e-etica-em-pesquisa/projetos-de-pesquisa-plataforma-brasil

Pontes, A. S. (2010). Origami modular, geometria espacial e deficiência visual (Modular Origami, Spatial Geometry and Visual Impairment). Licentiate Monography in Mathematics. Campus dos Goytacazes. RJ. Instituto Federal de Educação, Ciência e Tecnologia Fluminense. http://bd.centro.iff.edu.br/xmlui/handle/123456789/514

Rêgo, R. G., Rêgo, R. M., \& Gaudencio Jr., S. (2003). A geometria do Origami: atividades de ensino através de dobraduras (Geometry of Origami: Teaching Activities through Folding). João Pessoa, PB: Editora Universitária da Universidade Federal da Paraíba, UFPB.

Reily, L. H. (2004). Escola Inclusiva: Linguagem e Mediação. (Inclusive School: Language and 
Mediation). Campinas, SP: Papirus Editora,.

Rezende, E. Q. F., \& Queiroz, M. L. B. (2000). Geometria Euclidiana Plana e Construções Geométricas (Euclidean Plane Geometry and Geometric Costructions). Campinas, SP: Editora da UNICAMP.

Sá, E. D. De, Campos, I. M. De, \& Silva, M. B. C. (2007). Atendimento Educacional Especializado: Deficiência Visual (Epecialized Educational Service: Visual Impairment). São Paulo: Ministério da Educação, MEC/SEESP.

Suzuki, S. S., Marques, R. C., \& Parra, D. A. (2006). Geometria do Origami (Origami Geometry). Universidade Estadual de Campinas.

http://www.ime.unicamp.br/ eliane/ma241/trabalhos/origami.pdf

\section{Submit or recommend next manuscript to SCIRP and we will provide best service} for you:

Accepting pre-submission inquiries through Email, Facebook, LinkedIn, Twitter, etc. A wide selection of journals (inclusive of 9 subjects, more than 200 journals)

Providing 24-hour high-quality service

User-friendly online submission system

Fair and swift peer-review system

Efficient typesetting and proofreading procedure

Display of the result of downloads and visits, as well as the number of cited articles

Maximum dissemination of your research work

Submit your manuscript at: http://papersubmission.scirp.org/

Or contact ce@scirp.org 